\title{
The safety behavior on the health screening system during pandemic COVID-19 in the university setting
}

\author{
Muhammad Fikri Nur Fahmi ${ }^{1}$, Hera Nirwati $^{2}$, and Supriyati Supriyati ${ }^{3 *}$ \\ ${ }^{1}$ Health Behaviour, Environment and Social Medicine Department, Faculty of Medicine, Public Health and Nursing, Universitas \\ Gadjah Mada Yogyakarta, Indonesia \\ ${ }^{2}$ Department of Microbiology, Faculty of Medicine, Public Health and Nursing, Universitas Gadjah Mada Yogyakarta, Indonesia \\ ${ }^{3}$ Department of Health Behavior, Environment, and Social Medicine, Faculty of Medicine, Public Health and Nursing, Universitas \\ Gadjah Mada Yogyakarta, Indonesia
}

\begin{abstract}
Background: Universitas Gadjah Mada (UGM) had been creating health screening system as health promoting university (HPU) program. The Coronavirus Disease (COVID-19) was improve the potentially risk among health screening system officer. This study was aimed to explore the safety behavior of the health screening system officer during pandemic in UGM. Method: Qualitative study had been done in UGM Yogyakarta. This study was carried out in April - June 2021. In-depth interview and observation had performed to collect data. The research subject were health screening system officer and the leader of HPU in the faculty setting. Data was analyzed by using Open Code 4.02 software. Trustworthiness was carried out by using triangulation and peer debriefing. Result: Five of 18 faculties had applied health screening system structurally. The infrastructure, officers' recruitment system, and activities were varied among faculty. During the pandemic, officer should be involved in the preventing and controlling COVID-19 in their faculty. Meanwhile, the health screening system had been conducting in different setting by considering the safety principles. In addition, officers expressed their need to improve their capacity for conducting regular activities. Conclusion: The health screening system activities during pandemic in UGM was considering safety principles. Keywords: safety behaviour; health promoting university; health screening system; prevention; university setting
\end{abstract}

\footnotetext{
* Corresponding author: fikrijunior28@mail.ugm.ac.id
} 


\section{Background}

Universitas Gadjah Mada (UGM) has launched the Health Promoting University (HPU) program by cooperating with Mahidol University which is the representative of Health Promoting University at the Southeast Asian level [1]. There are seven focus of the HPU UGM, which are (1) health literacy; (2) healthy diet; (3) Physical activity; (4) mental health; (5) zero tolerance of alcohol and drug abuse; (6) zero tolerance of bullying and sexual harassment; as well as (7) healthy environment and disable friendly. In addition, a community based integrated post Posbindu had been developed as the basic health screening system in UGM as a part of HPU program.

Posbindu is a community-based promotion and prevention in order to early detection and monitoring disease risk factors, especially for the non communicable disease (NCD) ${ }^{(2)}$. Posbindu is consists of five steps activities, such as registration, assessing the health behaviour related to NCD risk factors, weighing and measuring, screening of helath status indicators (blood pressure, blood glucose, cholesterol etc), and health education and counselling as the follow up of the result of screening. The Posbindu NCD activities have a high risk of accidents due to needle sticks which result in the risk of contracting disease. Diseases that are transmitted from needle sticks are diseases that are transmitted by blood-borne microorganisms, namely HIV/AIDS, hepatitis B and hepatitis $\mathrm{C}^{[2]}$. The risk of Posbindu health cadres is increasing during the COVID-19 pandemic. The risk of Posbindu NCD cadres during the COVID-19 pandemic is contracting COVID-19 due to Posbindu NCD activities that check many people. World Health Organization (WHO) explained that of 35 million health workers, 3 million were exposed to blood, of which 2 million were exposed to the hepatitis B virus, 0.9 million were exposed to the hepatitis $\mathrm{C}$ virus and 170,000 were exposed to the HIV/AIDS virus [3]. Therefore, this study was aimed to explore the safety behaviour of Posbindu health cadres during COVID-19 pandemic in Universitas Gadjah Mada.

\section{Method}

The study was carried out by using qualitative method with case study design ${ }^{[4]}$. The uniqueness is that UGM is the pioneer of HPU at the ASEAN level and the changing role of Posbindu cadres in the COVID-19 pandemic. The research was conducted in April - June 2021 in Universitas Gadjah Mada Yogyakarta Indonesia.

The research subject were posbindu health cadres and faculty coordinator of HPU. Ten posbindu cadres and five HPU coordinators were chosen purposively. They were came from the Faculty of Medicine, Public Health and Nursing; Faculty of Engineer; Faculty of Social and Political Sciences; Faculty of Dentistry, as well as Faculty of Pharmacy UGM. In-depth interviews and observation was applied to collect the data. In- depth interviews was conducted online due to the COVID-19 pandemic. In addition, triangulation and peer debriefing was carried out for the trustworthiness strategy.

Research instrument was in-depth interview guidelines, audio recording, zoom application and field note. Furthermore, data was analysed by using open code 4.02 software.

This study was approved by the Ethical Committee of The Faculty of Medicine, Public Health and Nursing (Ref. No.: KE/FK/0362/EC/2021). In addition, verbal consent was conducted for each informant.

\section{Result}

\subsection{Respondent Characteristics}

There was 15 informants that had been interviewed in this study, as Table 1.

Table 1. Respondents characteristic

\begin{tabular}{llll}
\hline Position & Age & Gender & Education \\
\hline Officer & 52 yo & Female & Senior high school \\
Officer & 46 yo & Male & Senior high school \\
Officer & 36 yo & Female & 3-year Diploma \\
Officer & 43 yo & Female & Master \\
Officer & 28 yo & Female & 3-year Diploma \\
Officer & 40 yo & Male & Senior high school \\
Officer & 51 yo & Female & Senior high school \\
Officer & 40 yo & Male & Senior high school \\
Officer & 57 yo & Female & Senior high school \\
Officer & 54 yo & Male & Bachelor \\
Leader & 43 yo & Male & Doctoral degree \\
Leader & 46 yo & Female & Doctoral degree \\
Leader & 40 yo & Female & Doctoral degree \\
Leader & 49 yo & Female & Bachelor \\
Leader & 45 yo & Male & Bachelor \\
\hline
\end{tabular}

The education background of respondents was vary, from senior high school until doctorate degree. Most of respondent were had senior high school education background for the posbindu health cadre. On the other hand, most of the HPU faculty person in charge was completed the doctorate degree program.

Respondents were age $28-51$ years old, and $60 \%$ respondent were female. Data not only collected from respondent in Table 1. This study also conducted short conversation with the user of Posbindu during observation.

\subsection{Posbindu as the screening program for the university community}

Universitas Gadjah Mada had declared as health promoting university since July 2019. Furthermore, every faculty in UGM had person in charge for developing HPU program. The HPU program and its implementation was vary between faculties. It was depend of their need and available resources in the faculty. 
There were five faculty that had been developed Posbindu, i.e. Faculty of Medicine, Public Health and Nursing, Faculty of Engineer, Faculty of Sosial and Political sciences, Faculty of Dentistry, and Faculty of Pharmacy. Most of them were came from the health faculty cluster.

Basically, the posbindu was applied 5 steps of posbindu from the ministry of health Republic Indonesia. But still, the implementation was vary, as Table 2.

Table 2. Posbindu in the HPU UGM

\begin{tabular}{|c|c|c|c|c|c|}
\hline Variable & $\begin{array}{l}\text { Posbindu } \\
1\end{array}$ & Posbindu 2 & Posbindu 3 & $\begin{array}{l}\text { Posbindu } \\
4\end{array}$ & $\begin{array}{l}\text { Posbindu } \\
5\end{array}$ \\
\hline $\begin{array}{l}\text { Place of } \\
\text { Posbind } \\
u\end{array}$ & $\begin{array}{l}\text { Open } \\
\text { space, } \\
\text { tentative }\end{array}$ & $\begin{array}{l}\text { Certain } \\
\text { room, in } \\
\text { every } \\
\text { departme } \\
\mathrm{n}\end{array}$ & $\begin{array}{l}\text { Certain } \\
\text { room, only } \\
\text { one place }\end{array}$ & $\begin{array}{l}\text { Open } \\
\text { space, } \\
\text { tentative }\end{array}$ & $\begin{array}{l}\text { Open } \\
\text { space, } \\
\text { tentative }\end{array}$ \\
\hline services & $\begin{array}{l}\text { Basic } \\
\text { services, } \\
\text { physical } \\
\text { activities } \\
\text { and } \\
\text { healthy } \\
\text { diet } \\
\text { counsellin } \\
\text { g }\end{array}$ & $\begin{array}{l}\text { Basic } \\
\text { services }\end{array}$ & $\begin{array}{l}\text { Basic } \\
\text { services, } \\
\text { physical } \\
\text { activities } \\
\text { and } \\
\text { healthy } \\
\text { diet } \\
\text { counsellin } \\
\text { g }\end{array}$ & $\begin{array}{l}\text { Basic } \\
\text { services }\end{array}$ & $\begin{array}{l}\text { Basic } \\
\text { Services }\end{array}$ \\
\hline Team & $\begin{array}{l}\text { Health } \\
\text { cadre }\end{array}$ & $\begin{array}{l}\text { Health } \\
\text { cadre }\end{array}$ & $\begin{array}{l}\text { Health } \\
\text { cadre }\end{array}$ & $\begin{array}{l}\text { Temporar } \\
\text { y team }\end{array}$ & $\begin{array}{l}\text { Temporar } \\
\text { y team }\end{array}$ \\
\hline $\begin{array}{l}\text { Coverag } \\
\mathrm{e}\end{array}$ & $\begin{array}{l}\text { Lecturer, } \\
\text { faculty } \\
\text { staff }\end{array}$ & $\begin{array}{l}\text { Lecturer, } \\
\text { faculty } \\
\text { staff, } \\
\text { student }\end{array}$ & $\begin{array}{l}\text { Lecturer, } \\
\text { faculty } \\
\text { staff }\end{array}$ & $\begin{array}{l}\text { Lecturer, } \\
\text { faculty } \\
\text { staff }\end{array}$ & $\begin{array}{l}\text { Lecturer, } \\
\text { faculty } \\
\text { staff }\end{array}$ \\
\hline Time & $\begin{array}{l}\text { Certain, } \\
\text { regularly }\end{array}$ & $\begin{array}{l}\text { Certain, } \\
\text { regularly }\end{array}$ & $\begin{array}{l}\text { Certain, } \\
\text { regularly, } \\
\text { and by } \\
\text { appointme } \\
\text { nt }\end{array}$ & $\begin{array}{l}\text { Certain, } \\
\text { regularly }\end{array}$ & Uncertain \\
\hline $\begin{array}{l}\text { Training } \\
\text { for team } \\
\text { member }\end{array}$ & $\begin{array}{l}\text { Morethan } \\
4 \text { times }\end{array}$ & 4 times & 4 times & - & - \\
\hline
\end{tabular}

Table 2 showed that the implementation of Posbindu in UGM was considering the guideline from the Ministry of Health Republic Indonesia. Some of them had been tried to innovate and add other services, such as health eduction and councelling for healthy diet, physical activities as well as stop smoking councelling. The councelling not only for the participant who had a problem related to healthy behaviour. Every single participant was allow to get those health education and councelling. Health cadre was faculty staf that was recruited and got some training to improve their capacity. The team capacity improvement was conducted based on the health cadre need assessment. Unfortunately, the councelling had been done by health professional, instead of the health cadres.

In the early pandemic COVID-19 the Posbindu in UGM was stop. The health cadre involving the COVID-19 prevention and control. They were assigned to make sure that every faculty member who comes to campus obey the health protocols. Training and capacity building was conducted before they do their new task. Beside, the HPU coordinator only select health cadre who fulfilled inclusion criterias for those new task.

In the new normal period, the HPU faculty coordinator had prepared a new services model of posbindu. The posbindu should be conducted by considering the safety principles, safety for the user and also for health cadres. The Posbindu was carried out by implementing health protocol, namely $3 \mathrm{M}$ (wearing mask properly, physical distancing and crowd avoidance, wash hand regularly).

\subsection{Safety behaviour of the health cadre}

Table 3 describe the safety behaviour of the posbindu health cadres in UGM.

Table 3. Safety behavior of health cadre

\begin{tabular}{|c|c|c|}
\hline Category & Sub category & codes \\
\hline \multirow[t]{2}{*}{$\begin{array}{l}\text { Washing } \\
\text { hand } \\
\text { regularly }\end{array}$} & $\begin{array}{l}\text { Time to wash } \\
\text { hand }\end{array}$ & $\begin{array}{ll}- & \text { After exercise } \\
\text { - } & \text { Often } \\
\text { - } & \text { Before give services in } \\
\text { posbindu } \\
\text { - } \text { Before eat } \\
\text { - } \text { When the posbindu finished }\end{array}$ \\
\hline & $\begin{array}{l}\text { Facilities for } \\
\text { hand washing }\end{array}$ & $\begin{array}{l}\text { - Many places } \\
\text { - Every single table in } \\
\text { Posbindu }\end{array}$ \\
\hline \multirow[t]{2}{*}{$\begin{array}{l}\text { Using } \\
\text { lancet } \\
\text { needle } \\
\text { safely }\end{array}$} & $\begin{array}{l}\text { Single use } \\
\text { lancet needle }\end{array}$ & $\begin{array}{l}\text { - Disposable lancet needle } \\
\text { - One lancet needle for one } \\
\text { person } \\
\text { - Communal needle is } \\
\text { harmful }\end{array}$ \\
\hline & $\begin{array}{l}\text { Critical time of } \\
\text { injury }\end{array}$ & $\begin{array}{l}\text { - Opening the lancet needle } \\
\text { - Closing the lancet needle } \\
\text { - Waste of lancet needle }\end{array}$ \\
\hline \multirow[t]{2}{*}{$\begin{array}{l}\text { Wearing } \\
\text { Personal } \\
\text { Protective } \\
\text { Equipment } \\
\text { properly }\end{array}$} & $\begin{array}{l}\text { Wearing } \\
\text { handscoon }\end{array}$ & $\begin{array}{l}\text { - Washing hand before } \\
\text { - Washing hand after } \\
\text { - Put it out our bracelet } \\
\text { - Covering full hand } \\
\text { - Do not tounch out of glove } \\
\text { - Open glove from inside } \\
\text { - Remove glove when exposed } \\
\text { to blood }\end{array}$ \\
\hline & $\begin{array}{l}\text { Wearing a } \\
\text { protective mask }\end{array}$ & $\begin{array}{ll}\text { - } & 2 \text { ply fabric mask } \\
\text { - } & \text { Medical mask } \\
\text { - } & \text { Covering mouth and nose }\end{array}$ \\
\hline
\end{tabular}

According to the observations, we found that there were different model of the posbindu before and as long as the COVID-19 pandemic. The safety behavior was applied strictly in the pandemic era. The Posbindu that had been doing in the pandemic era was followed by health protocols. Besides, the facilities to support safety behavior was improved. Hand washing places, hand sanitizer and safety behavior warning sign was placed placed everywhere.

Before pandemic era, handsanitizer only put at the table 1 and 4 of the posbindu. In contrast, in the pandemic era, handsanitizer was provided in every single table of posbindu.

The observation of the using the lancet needle behavior showed that the Posbindu cadre on duty at table 4 opened the needle by turning and then inserting the lancet needle to the needle cover before disposed of in the safety box. Posbindu NCD cadres use a disposable lancet needle. This behaviour had been done in the Posbindu HPU UGM before and during the pandemic COVID-19.

In contrast, there were differences behavior of using personal protective equipment (PPE) of Posbindu cadre before and during the COVID-19 pandemic. Before pandemic, all of not all Posbindu 
cadre wearing a mask when they served posbindu. Meanwhile, the PPE that had been used health cadre during the pandemic were mask and handscoons. We found that there was different behaviour among health cadre related to the handscoons use, especially the way to remove handscoon. Most of them were aware and did it carefully by keep the hands from touching the outer part of the handscoon and the others directly remove the handscoon.

\subsection{Posbindu Cadre involved in the COVID-19 prevention and control}

This study showed that the responsibility of Posbindu cadre was changing over time. First, Posbindu cadre responsibily was focus on the non communicable disease prevention. Pandemic COVID-19 is a communicable disease. Then posbindu cadre should be involved in the COVID-19 prevention and control.

The responsibility of the Posbindu cadres not limited to serve the posbindu, but also had to monitor the implementation of the health protocol implementation of the faculty member. For example, the need to check the body temperature and reminder faculty member to wash their hand or wearing mask properly, as quotes below.

"...we are scheduled to standby at the entry points of building such as IKM building, radioputro, graha wiyata, KPTU building to check body temperature and reminder wash hand first before enter the building..." (Posbindu cadre, female, 52 years old).

"...(the job) looks like COVID-19 task force" (posbindu cadre)

“..Posbindu cadre and cleaning service need to collaborate for the desinfection ..." (posbindu cadre, male, 40 years old).

"....The Posbindu cadre have a new job as COVID-19 task force during the pandemic... then to assistance for vaccines 1 and 2 for lecturer, elderly and non elderly staff and all academic community members ..." (cadre, male, 40 years old).

"...help to prepare blood test kit as long as the staff is on duty, i am the one serving ..." (cadre, female, 57 years old).

The additional task of the posbindu cadre also vary between faculties. Some of them also become tracing team for the COVID-19, and or COVID-19 screening by using GENOSE.

"... if we work from office, we have to trace the close contact of COVID-19 patient.." (cadre, male, 40 years old).

"...all the campus staff that work form office is must to check genose and now, everyone has to check genose" (cadre, male, 54 years old).

\section{Discussion}

\subsection{Safety Behaviour for Posbindu NCD Cadres}

\subsubsection{Safety Behaviour in Washing Hands}

Hand washing is one of the safety behaviors because it can prevent posbindu NCD cadres from contracting the disease. Posbindu NCD cadres said that when they wash their hands they use soap and wash in flowing water. Washing hands with soap or using a hand scrub has been shown to reduce the concentration of germs on hands. Washing hands with soap and using alcoholbased hand sanitizers have been shown to be effective in reducing the level of virus concentration on hands [5]. There is a difference between the number of germs on the palms based on compliance with the implementation of handwashing [6].

However, there were also Posbindu NCD cadres who said that they did not wash their hands with soap because soap was not available. The results of observations made by researchers also showed differences in hand washing facilities between Posbindu NCD activities before and during the COVID-19 pandemic. Posbindu NCD activities before the COVID-19 pandemic for hand sanitizers were only provided at Tables 1 and 4. While Posbindu NCD activities during the hand sanitizer pandemic were placed at each Posbindu NCD table. Hand washing facilities are available, soap, a guide to the sequence of 6 steps for washing hands. The cadres and participants of the Posbindu NCD must wash their hands and check their body temperature before entering the Posbindu NCD.

Facility is an important factor in the efforts of Posbindu NCD cadres to behave in safety. Facilities and infrastructure are the main facilities to support the culture of handwashing. Handwashing facilities are very influential on hand washing behavior [7].

Posbindu NCD cadres have different answers in the sequence of handwashing steps and when to wash hands during Posbindu NCD activities. There are Posbindu NCD cadres who wash their hands in the order of washing using flowing water and soap on the inner and outer palms, then between the fingers and continue to rub the palms until they finish washing their hands and there is also a Posbindu NCD cadre who admits that he forgot the order. Handwashing steps and some have implemented 6 handwashing steps according to the World Health Organization (WHO).

There are also Posbindu NCD cadres who admit that they have difficulty implementing hand washing in accordance with the 6 steps of handwashing according to the World Health Organization (WHO). Posbindu NCD cadres think that the most important thing in washing hands is to rub the back of the hand, palms, fingers until clean and make sure all parts of the hands have been washed.

Posbindu NCD cadres also have different opinions regarding the time to wash their hands. The 
Posbindu NCD cadre said that the time to wash hands was before taking action before using the handscoon, while other Posbindu NCD cadres thought that the time to wash hands was after the examination, after removing the medical gloves.

Differences in hand washing steps between Posbindu NCD cadres, Posbindu cadres who forget the correct order of hand washing steps and posbindu cadres who have difficulty implementing hand washing steps and hand washing time when Posbindu NCD activities are influenced by lack of knowledge and educational background, management commitment and lack of supervision by the leadership of Posbindu NCD. Knowledge is the main factor that can make the right behavior happen and make that behavior lasting and become a culture in a particular team or organization. Knowledge and attitudes are strongly related to the act of washing hands [8].

Posbindu NCD cadres who apply hand washing according to WHO standards have an educational background in the health sector, namely as dental nurses. Educational background does have an effect on hand washing behavior. Nursing students had a significant level of hand hygiene compliance [9].

Posbindu NCD management also needs to be fully committed and supervise Posbindu NCD cadres so that Posbindu NCD cadres can apply handwashing in the order of handwashing. Supervision by Posbindu NCD leaders to Posbindu NCD cadres regarding hand washing also needs to be done. One way of supervising in order to increase handwashing is with Closed Circuit Television (CCTV). Closed Circuit Television (CCTV) can be used to improve handwashing compliance. CCTV has been shown to significantly improve hand washing compliance, including compliance with five moments of handwashing and six steps of hand washing [10].

Supervision carried out by Posbindu leaders requires a strong commitment from Posbindu management. Hand washing compliance is very significantly related to supervision, the better the supervision is, the higher the level of compliance in hand washing will also increase. So it is necessary to carry out stricter supervision of Posbindu NCD cadres in washing hands because supervision is one of the determinants of the quality of handwashing [11].

\subsubsection{Safety Behaviour in Using Lancet Needles.}

Safety behavior in the use of lancet needles is important for posbindu cadres to pay attention to. The Posbindu NCD activity that uses a lancet needle is the blood test at table 4. Posbindu cadres are at risk of work accidents being punctured by needles from the blood of Posbindu NCD participants which can cause Posbindu NCD cadres to contract HIV/AIDS, hepatitis $\mathrm{B}$, and hepatitis $\mathrm{C}$.

The results of interviews conducted with Posbindu NCD cadres explained that when opening the lancet needle cover by turning the needle tip and after using it, the needle was closed first with a small fracture from the needle cover. However, in the process of closing the needle with a small fracture from the needle cover, there are Posbindu NCD cadres who do not know this stage. Posbindu NCD cadres also said that the lancet needle was used for one person only. The behavior carried out by Posbindu NCD cadres is a safety behavior that can minimize the risk of exposure to lancet needles to others.

Posbindu NCD cadres are not aware of safety behavior in using lancet needles because the Posbindu NCD cadres have never served at Table 4. Lack of knowledge of Posbindu cadres can cause needle stick accidents at Posbindu NCD. Posbindu NCD cadres who do not know safety behavior in using lancet needles are caused by a lack of knowledge in Posbindu NCD activities, especially at table 4 .

Posbindu NCD cadres' knowledge of procedures for using lancet needles will affect safety behavior and safety culture in posbindu cadres at Gadjah Mada University. The level of knowledge had a significant relationship with the application of occupational safety and health. Knowledge of occupational safety and health is good, the application of occupational safety and health will also be good [12].

Knowledge is also related to work accidents. Knowledge is related to the incidence of needle sticks in health workers, so it is necessary to conduct training and counseling to health workers so that the incidence of needle sticks can be minimized [13].

\subsubsection{Safety Behaviour in using PPE}

Safety behavior that needs to be considered in Posbindu NCD activities is the use of personal protective equipment. The personal protective equipment used in Posbindu NCD activities before the pandemic was a handscoon, while during the pandemic they were masks and handscoon.

The PPE used by Posbindu NCD cadres when the new normal should be masks, handscoons and face shields. Lack of knowledge affects to the behavior of using PPE in Posbindu NCD cadres [14, 18] Knowledge of the use of PPE also affects compliance with the use of PPE [18].

Personal protective equipment must be used and removed in a proper manner. The results of interviews conducted with Posbindu NCD cadres regarding safety behavior in the use of handscoons obtained different results. Posbindu NCD cadres remove the handscoon by rolling it, folding the ends of the handscoon and forgetting how to remove the handscoon correctly. Posbindu NCD cadres when asked about the reason for changing the handscoon, they answered with a different question. The Posbindu NCD cadre remove the handscoon for reasons of going to the bathroom, while the other Posbindu NCD cadres answered when the handscoon had blood on it. The frequency of using handscoons carried out by Posbindu cadres is 3-4 times per posbindu activity.

So it is necessary to provide counseling and training regarding PPE to Posbindu NCD cadres and management commitment so that Posbindu NCD cadres can know and use PPE appropriately. Health 
professional support, and social support from colleagues and the provision of information in the form of counseling and training were proven to be able to increase health workers in the use of PPE [14, 18]. Counseling is proven to be able to increase knowledge and behavior in the use of personal protective equipment [15].

Based on the results of the interview, it was also found that Posbindu NCD cadres when changing handscoons will wash their hands using hand sanitizer. Hand sanitizer is proven to be effective in reducing germs, bacteria and viruses on hands. Washing hands with soap and using alcohol-based hand sanitizers have been shown to be effective in reducing the level of virus concentration on hands [16].

\subsection{The role of Posbindu NCD during the Pandemic COVID-19.}

According result from interview and observation Posbindu cadres during the covid-19 pandemic played a very important role in the process of preventing occupational diseases due to covid-19 within the Gadjah Mada University.

NCD Posbindu cadres are assigned the task of check GeNose, officers who measure body temperature and recommend hand washing to lecturers and employees of Gadjah Mada University who are in charge of work from the office (WFO), the faculty team of the Covid-19 task force, manufacture of hand sanitizers, manufacture of transport viruses. medium (VTM), a tracing officer at the faculty tasked with tracing the staff of lecturers and employees who when the WFO runs out of contact with anyone and if anyone is positive for covid, they will trace (tracing) the history of contact with humans and the history of rooms that have been visited, officers disinfect tools and equipment a room to prevent the transmission of covid-19 in the workplace, officers who make SOPs regarding health protocols at the faculty, officers who provide assistance when lecturer staff and employees are vaccinated against covid-19 and carry out posbindu activities in the new normal era.

Tracing is associated with better Covid-19 control. Effective tracing depends on how many and how quickly contacts are traced and effective quarantine can prevent transmission [17]. Tracing conducted at UGM has used an application that is useful for tracing the history of contact with humans and the history of rooms that have been visited by the UGM academic community who carried out WFO.

GeNose is a tool to detect and diagnose someone infected with Covid-19 or not with just one breath created by Gadjah Mada University. The advantages of genose are that the results issued are faster, accurate but simple and the examination costs are cheap [18]. This advantages is useful for Posbindu NCD cadres who the majority do not have a medical education background, so Posbindu NCD cadres who have been trained can use GeNose directly.

Researchers explain information to research subjects about the rights and obligations of research subjects and guarantee secret of information provided by research subjects. Information provided only used for study purposes. Secret information, rights and obligations of research subjects are written in informed consent.

The limitation research in this study is inadequate signal so that when conducting online interviews, researchers and has to turn off the camera so that researchers has difficulty seeing the expressions of informants and the work from office policy for Gadjah Mada University staff causes researchers to schedule interviews so that it takes longer to collect data.

\section{Conclussion and Recommendation}

The study concluded that the posbindu health cadre in UGM was applied safety behaviour to protect their self and also to protect others through many activies. During pandemic COVID-19, they also involved in the COVID-19 prevention and control. Their responsibility was not limited to serve faculty member on the Posbindu, but also responsible to monitor the health protocols implementation, COVID-19 screening by using GeNose, as well as conduted tracing for the close contact of the COVID-19 patient in their own faculty.

Leaders of Posbindu NCD need to improve safety behavior by conducting counseling and training, increasing commitment, increasing supervision, providing the necessary facilities, and infrastructure NCD Posbindu leaders must pay attention to the safety and health of Posbindu NCD cadres on duty during the COVID-19 pandemic because Posbindu NCD cadres are at high risk of contracting COVID-19.

\section{References}

1. Satria, UGM Luncurkan health promoting university dalam pembukaan lustrum XIV, (2019). Available from: https://ugm.ac.id/id/berita/18126ugm-luncurkan-health-promoting-universitydalam-pembukaan-lustrum-xiv

2. Kementrian kesehatan, Situasi dan analisis Hepatitis, Pusat data dan informasi, Jakarta (2014).

3. WHO, Aide-memoire for a strategy to protect health workers from infection with bloodborne viruses, Geneva (2003)

4. Yin, Case study research design and methods $\left(4^{\text {th }}\right.$ ed. Vol), Sage Publication. (2009)

5. M. Grayson, S. Melvani, J. Druce, I. Barr, S. Ballard, P. Johnson, T. Mastorakos, C. Birch, Efficacy of soap and water and alcohol-based hand-rub preparations against live H1N1 influenza virus on the hands of human volunteers. Clinical infectious diseases, 48, 3 (2009)

6. I. Santri, F. Dewi \& H. Nirwati, Perbedaan angka kuman di telapak tangan perawat menurut angka tingkat pengetahuan dan kepatuhan pelaksanaan 
cuci tangan di rumah sakit swasta. Berita Kedokteran Masyarakat, 33, 3 (2017)

7. Waryantini, F. Pratama, Hubungan sikap perawat dengan tingkat kepatuhan dalam melakukan langkah-langkah mencuci tangan di unit pelaksana teknis pelayanan kesehatan. Healthy Journal | Jurnal Ilmiah Kesehatan Ilmu Keperawatan, 7, 2 (2021)

8. A. Lestari, Hubungan pengetahuan dan sikap terhadap perilaku cuci tangan pada masyarakat kelurahan pegirian. Jurnal Promkes. 7, 1 (2019)

9. L. Labrague, D. Mcenroe-petitte, T. Mortel, A. Nasirudeen, A systematic review on hand hygiene knowledge and compliance in student nurses. International Nursing Review. 65, 3 (2017)

10. A. Ramadhani, I. Dwiprahasto, H. Nirwati, Utilization of closed circuit television in improving nurses compliance with hand hygiene in budhi asih hospital, Jakarta. Jurnal keperawatan soedirman, 15, 2 (2020)

11. S. Banjarnahor, A. Ragini, Hubungan pengawasan infection prevention and control link nurse (IPCLN) terhadap kepatuhan perawat melakukan cuci tangan di ruang rawat inap murni teguh memorial hospital medan. Indonesian Trust Health Journal, 1, 1 (2018)

12. N. Hanifa, T. Respati, Y. Susanti, Hubungan pengetahuan dengan upaya penerapan K3 pada perawat. In Bandung Meeting on Global Medicine \& Health (BaMGMH), 1, 1 (2017)

13. S. Mapawanang, K. Pandelaki, J. Panlewen, Hubungan antara pengetahuan, kompetensi, lama kerja, beban kerja dengan kejadian tertusuk jarum suntik pada perawat di RSUD Liun kedage Tahuna. Jurnal EMBA. 5, 3 (2017)

14. E. Clays, D. Bacquer, V. Crasset, F. Kittel, P. Smet, M. Kornitzer, R. Karasek, G. Backer, The Perception of Work Stressors is Related to Reduced Parasympathetic Activity. International Archives of Occupational and Environmental Health, 84, 2 (2010)

15. R. Simanjuntak, Solichin, E. Fanani, Pengaruh Penyuluhan Terhadap Peninkatan Perilaku Penggunaan Alat Pelindung Diri. Preventia: The Indonesian Journal of Publik Health 1, 2 (2016)

16. C. Juneau, A. Briand, T. Pueyo, P. Colazzo, L. Potvin, Effective contact tracing for COVID-19: A Systematic Review. MedRxiv, (2020)

17. W. Gunardi, Pemeriksaan diagnosis laboratorium COVID-19: keterbatasan dan tantangannya saat ini. Jurnal Kedokteran Meditek, 27, 2 (2021)

18. R.Zahara, S. Effendi, N. Khairani, Kepatuhan menggunakan Alat Pelindung Diri (APD) Ditnjuau dari Pengetahuan dan Perilaku pada Petugas Instalasi Pemeliharaan Sarana dan Prasarana Rumah Sakit (IPSRS). Aisyah: Jurnal Ilmu Kesehatan, 2, 2 (2017) 